\title{
Vincent Laisney, Cénacles et cafés littéraires: deux sociabilités antagonistes
}

Damiano Sinfonico

\section{(2) OpenEdition}

1 Journals

\section{Edizione digitale}

URL: http://journals.openedition.org/studifrancesi/5730

DOI: $10.4000 /$ studifrancesi.5730

ISSN: 2421-5856

\section{Editore}

Rosenberg \& Sellier

\section{Edizione cartacea}

Data di pubblicazione: 1 septembre 2011

Paginazione: 448

ISSN: 0039-2944

\section{Notizia bibliografica digitale}

Damiano Sinfonico, «Vincent Laisney, Cénacles et cafés littéraires: deux sociabilités antagonistes», Studi Francesi [Online], 164 (LV | II) | 2011, online dal 30 novembre 2015, consultato il 13 janvier 2021. URL: http://journals.openedition.org/studifrancesi/5730 ; DOI: https://doi.org/10.4000/studifrancesi.5730

Questo documento è stato generato automaticamente il 13 janvier 2021.

\section{(c) $(7)$}

Studi Francesi è distribuita con Licenza Creative Commons Attribuzione - Non commerciale - Non opere derivate 4.0 Internazionale. 


\title{
Vincent Laisney, Cénacles et cafés littéraires: deux sociabilités antagonistes
}

\author{
Damiano Sinfonico
}

\section{NOTIZIA}

VINCENT LAISNEY, Cénacles et cafés littéraires: deux sociabilités antagonistes, in «Revue d'histoire littéraire de la France», 2010, n. 3, pp. 563-588.

1 Per l'A. il caffè letterario è una leggenda nata nel Novecento, ad opera di pochi tardivi e nostalgici scrittori. L'A. si impegna ad analizzare i luoghi comuni intorno a questa istituzione, che per abitudine si è soliti considerare il cuore della vita letteraria di fine Ottocento, crogiolo e origine delle teorie estetiche fin de siècle, precursore delle avanguardie e della modernità. In realtà, l'opposizione troppo comoda tra l'imbalsamato salotto, aristocratico, accademico, e il più vivace caffè, democratico, scapigliato, non convince l'A., che ricorda la fortuna incontrastata delle riunioni da salotto ancora alla fine del secolo; mentre ritiene opportuno soffermarsi sulla distinzione tra caffè e cenacolo. Questo binomio offre realmente due fronti speculari, due immagini capovolte di una socialità letteraria biforcuta: da una parte il luogo caotico, ludico e talvolta lurido, dove persone di diversa formazione si ritrovano più per auto-promozione che per convinzione, dall'altra parte un luogo eletto, composto di pochi gregari raccolti attorno a un maestro riconosciuto, come le domeniche letterarie di Flaubert o le serate di Médan. L'A. conclude quindi con una provocazione, individuando il primo vero caffè letterario, nel «Cyrano» dei surrealisti, quando la leggendaria stagione d'oro dei Boulevards è ormai appena il bagliore di un ricordo sfocato. 